\title{
Dental Caries as a Measure of Diet, Health, and Difference in Non-Adults from Urban and Rural Roman Britain
}

\author{
Anna Rohnbogner ${ }^{1 *}$ \\ Mary Lewis ${ }^{1}$ \\ 1 University of Reading, UK
}

Keywords: dental disease, carious lesion, Romanisation, linear enamel hypoplasia, co-occurrence

\begin{abstract}
Dental disease in childhood has the potential to inform about food availability, social status, and feeding practices, in addition to contributing to a child's overall health status. This paper presents the first comprehensive overview of carious lesion frequencies in 433 non-adults (1-17 years), and 6,283 erupted permanent and deciduous teeth from 15 urban and rural Romano-British settlements. Pooled deciduous and permanent caries rates were significantly higher in major urban sites $(1.8 \%)$ compared to rural settlements $(0.4 \%)$, with children from urban sites having significantly higher lesion rates in the deciduous dentition $(3.0 \%)$, and in younger age groups with mixed dentitions. The differences in dental caries between urban and rural populations suggest disparities in maternal oral health, early childhood feeding practices, food preparation and access to refined carbohydrates. A richer, perhaps more 'Roman', cuisine was eaten in the urban settlements, as opposed to a more modest diet in the countryside. The effect of early childhood stress on caries frequency was explored using evidence for enamel hypoplasia. Co-occurrence of caries and enamel hypoplasia was highest in the major urban cohort $(5.8 \%)$ and lowest in the rural sample $(1.3 \%)$, suggesting that environmental stress was a contributing factor to carious lesion development in Romano-British urban children.
\end{abstract}

Child health is an understudied subject in the archaeology of Roman Britain. Most of what we know about growing-up in the province is derived from the Classical literature. While archaeological research has mainly focused on the architectural grandeur of the towns and high status villa settlements (Parkins, 1997; Millett, 2005; Mattingly, 2006; Pearce, 2008; Holbrook, 2015), rural settlements and their inhabitants have received scant attention, preventing a more holistic view of life in Britannia (Taylor, 2007; McCarthy, 2013; Breeze, 2014; Fulford and Holbrook, 2014). Contrary to the long-held belief in the detrimental effects of the urban environment, recent bioarchaeological research has demonstrated that living in the Romano-British countryside also negatively affected health (Pitts and Griffin, 2012; Redfern et al., 2015). The late Romano-British villa economy may have provided health challenges for its workers, a subject yet to be fully explored. While nonadult skeletons are widely acknowledged to provide an intricate measure of population fitness in the past (Mensforth et al., 1978), comparisons of the morbidity and mortality of urban and rural Romano-British children have yet to be carried out. A child's diet would have reflected the cultural beliefs and social standing of his or her family. Carious lesion frequency can therefore provide valuable information on access to re- sources, eating habits, and food preparation practices.

In children, calcified plaque (calculus), and pathological conditions of the dentition such as periapical lesions, periodontal disease, and antemortem tooth loss are rare. Carious lesion frequencies in the deciduous and permanent teeth, therefore, provide the most effective measure for discussing past dental health during childhood (Halcrow et al., 2013). The presence of dental caries in children not only indicates the levels of carbohydrates consumed, but also informs on cultural practices such as pre-mastication, and sharing of foods or utensils (Nield et al., 2008). Carious lesions can cause considerable discomfort, resulting in intense pain, difficulty eating, reduced efficiency of the immune system (Baqain et al., 2004), and can affect speech development (Aligne et al., 2003). Dental studies that focus on children are rare in the palaeopathological literature and tend to focus on individual sites or have small sample sizes (e.g. Moore and Corbett, 1973; Whittaker et al.,

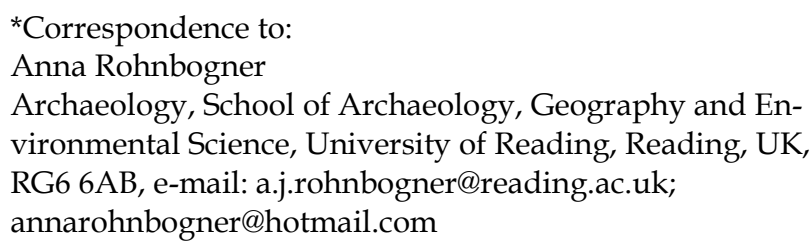
vironmental Science, University of Reading, Reading, UK, RG6 6AB, e-mail: a.j.rohnbogner@reading.ac.uk; annarohnbogner@hotmail.com 
1981; O'Sullivan et al., 1993; Clough and Boyle, 2010; Redfern et al., 2012). This study will provide an overview of carious lesion frequency in non-adults from 1st to early 5 th century AD urban and rural settlements in Roman Britain. Due to the general absence of periodontal disease, periapical lesions, antemortem tooth loss, and calculus in the dentitions of children, this study relies on dental caries as the sole measure of childhood dental health. The aim of the study is to assess whether an urban or rural living environment impacted childhood dental health through the investigation on lesion frequencies of dental caries in the deciduous and permanent dentition.

\section{Pathogenesis of dental caries in children}

Dental caries is a progressive infectious disease of the deciduous and permanent dentition, with localised demineralisation of the dental hard tissues by organic acids (Larsen, 1997). Streptococcus and Lactobacillus bacteria in the oral cavity metabolise sugars and starches, which create an acidic environment and demineralise tooth enamel (Byun et al., 2004). Teeth are remineralised as soon as $\mathrm{pH}$ levels are restored to neutral. If, however, the $\mathrm{pH}$ is low for a prolonged period, the dynamic between de- and re-mineralisation is upset, resulting in a cavity (Gussy et al., 2006). Streptococcus mutans, the main cariogenic bacterium, is normally transmitted from the mother or other caregiver to the child through kissing or sharing implements (Nield et al., 2008). Colonisation with S. mutans can commence as early as six months old, although the highest risk for infection is at two years old. It takes around 13-16 months from colonisation for a lesion to develop (Kawashita et al., 2011).

'Early Childhood Caries' defined as caries in children aged 0-5 years, is a serious chronic condition in the modern world (Afroughi et al., 2010). Newly erupted deciduous teeth are particularly susceptible to dental caries due to incomplete maturation, large dental tubules and thinner enamel, which is insufficient in preventing the progression of carious lesions (Aligne et al., 2003; Schuurs, 2013). The area around the erupting tooth also provides favourable conditions for bacterial colonisation (Schuurs, 2013). Child saliva flow rate is slower than in adults, and has lower levels of secretory immunoglobin A (IgA) concentrations. While IgA begins to be produced after one month of life, its formation can be impaired by high levels of cortisol in the blood through stress. Stress could therefore have a caries-promoting function. It may manifest as enamel defects, i.e. hypoplasia, which in turn may increase the risk of dental caries (Boyce et al., 2010). Enamel hypoplasias may cause dental caries to progress more quickly due to higher acid solubility of defective enamel, and greater adhesion of cariogenic bacteria at the site of a defect (Hong et al., 2009). The presence of enamel hy- poplasias in individuals with dental caries may therefore be a valuable indicator of early childhood stress in relation to dental decay, and it is of interest to evaluate their co-occurrence.

Using the jaws of modern children, Afroughi and colleagues (2010) showed that once a tooth is infected, dental caries continues to spread to the teeth on either side or above, often in a symmetrical pattern. Risk of lesion development was greater for maxillary posterior teeth than for anterior or mandibular teeth. Early childhood caries may take on a rampant virulent form, known as 'Severe Early Childhood Caries' (SECC), 'Nursing Caries' or 'Milk Bottle Syndrome'. The condition is characterised by rapid lesion development and dental decay primarily in the maxillary anterior dentition (Berkowitz, 2003; Azevedo et al., 2005). A probable case of SECC has recently been identified by Bonsall and colleagues (2015) in a 3-4 year old child from Roman Ancaster, Lincolnshire.

Diet is a crucial factor in the onset and proliferation of dental caries. Refined foods with a high carbohydrate and/or sugar content encourage the metabolic activity of oral bacteria and acid production, increasing the risk of lesion development (Powell, 1985; Prowse et al., 2008). A tough and fibrous diet has a cleaning effect, and vigorous mastication stimulates salivary flow, which is alkaline, buffering against plaque acids (Duray, 1992; Moynihan, 2000). Soft sticky foods and prolonged snacking or sipping of sweetened fluids pose a greater risk for acid development (Hallet and O'Rourke, 2003). Dental disease is usually described by the different surfaces of the tooth that are affected: the occlusal surfaces, smooth surfaces of the crown including the interproximal areas, or the root (Moore and Corbett, 1973). Each of these surfaces has different cariogenic potential, therefore, the location of carious lesions on the tooth may provide insight into changes in diet (Ortner, 2003). With the intensification of cereal agriculture, carious lesions at the root and cementoenamel junction rise, and with the introduction of refined sugars, interproximal and fissure carious lesions increase, especially in children (Hillson 1996, 283).

\section{The Romano-British diet}

There are a number of historical sources that make reference to 'Roman' food and drink, including Apicius' collection of recipes, Pliny the Elder's Naturalis Historia or Galen's medical writings (Grocock and Grainger, 2006; Alcock, 2010). These sources reflect Mediterranean practices of the literate upper classes in the 1st and 2nd centuries $\mathrm{AD}$, and it remains unknown how these are relevant for exploring diet in Roman Britain. When comparing literary evidence on diet to recent isotopic and osteological studies of populations from Rome (Rutgers et al. 2009; Killgrove and Tykot 2013), Velia (Craig et al. 2009), and Portus Romae 
(Prowse et al. 2008), it transpires that a 'typical' Roman diet as described in Classical sources may not have been followed, or in fact existed.

Cereal products such as bread and porridge may have been the staple foods in Britain, although variation across the social and geographical strata is expected (Cool, 2006). Sugars would have been available as fructose from fruits, fruit juices, honey and syrups, or glucose in the carbohydrates consumed (Moore and Corbett, 1973; Bowman and Thomas, 1994; Cool, 2006; Bogdanov et al., 2008; Nassar et al., 2012). More advanced farming and plant cultivation techniques, alongside larger scale animal breeding, would have ensured a stable food supply for the army and nonproducing urban population, whilst also putting increasing demands on the workers in the countryside (Mattingly, 1997; Dobney, 2001; Taylor, 2001; Pitts and Griffin, 2012; McCarthy, 2013; Redfern et al., 2015).

Studies by King $(1984 ; 1999 ; 2001)$ and Cummings (2009) have demonstrated that access to meat and animal products was dependent on site type and status. Overall, marine and freshwater fish became increasingly fashionable, probably as a result of following Roman tastes (Locker, 2007). Isotopic studies on human bones (Richards et al., 1998; Redfern et al., 2010; Cheung et al., 2012; Müldner, 2013) and archaeobotany (van der Veen, 2008; van der Veen et al., 2007; 2008) have revealed temporal, cultural, social and sex differences in the consumption of terrestrial, plant, and aquatic foods at an inter-site and intra-site level. Richard and colleagues' (1998) study of Poundbury Camp in Dorset showed that animal protein and marine foods were only available to the few. Children are thought to have enjoyed more marine foods, and diet was more varied for the inhabitants of the towns (Redfern et al., 2010; Müldner, 2013). It also appears that marine and freshwater foods were primarily consumed in the urban environment rather than the surrounding villages, and that the male and female diet, at least within Roman Gloucester, differed (Cheung et al., 2012). To the benefit of Britons, a variety of new plant foods were introduced following the Roman conquest, improving the nutritional value of the Romano-British diet. Examples include cherries, carrots, or plum, also beet and cabbage, which are high in nutrients and vitamins (van der Veen et al., 2008). As a general pattern, plant foods were widely accessible and eaten in both town and country (van der Veen et al., 2007). It is of note that some areas of the province differed. Access to new plant foods was more restricted, or perhaps opposed, in the southwest (van der Veen et al., 2008).

In children, dietary experiences would have started at weaning with the gradual introduction of solid foods to supplement breastmilk. Galen's writings and Soranus' Gynaecology, both dating to the 2nd century $\mathrm{AD}$, recommend the introduction of supplementary foods from around six months (Fildes, 1986; Temkin,
1991). Weaning would have been complete by $2-4$ years old, a practice that has been supported by isotopic analysis of non-adults from England and Italy (Fildes, 1986; Fuller et al., 2006; Prowse et al., 2008; Prowse, 2011; Nehlich et al., 2011; Redfern et al., 2012; Powell et al., 2014). The Roman weaning diet comprised mainly of cereal foods, such as porridge, or bread mixed with milk, wine or honey (Temkin, 1991; Garnsey, 1999). Pre -mastication of foods for weanlings was warned to be harmful; however, the fact that the practice needed to be discouraged suggests it was a known method of infant feeding (Bradley, 1986; Temkin, 1991). Honey was also used as a popular medicinal aid. Soranus suggests rubbing honey on the gums of teething infants to soothe their pain (Temkin, 1991). Once weaned, the contents of the Roman early childhood diet are unknown. If diet was influenced by location and status, children would have been subjected to differential food allocation. Child dental disease rates may then also differ, depending on urban and rural site types, or high versus low status settlements. A large scale investigation of dental caries rates may therefore provide the first detailed evidence for cultural practices and dietary habits of children in Roman Britain.

\section{Site classification}

\section{MATERIALS AND METHODS}

The terms 'urban' and 'rural' are used to characterise the nature of the settlement rather than its geographic locale. In order to allow for a comparison of carious lesion frequencies between settlements under different levels of Roman influence, sites were divided into major urban (coloniae, civitates), minor urban (nucleated/small towns) and rural settlements (villages, farmsteads, villa estates). A common denominator for Romano-British towns, whether large or small, is the dependence on the hinterland for agricultural surplus to feed the non-producing urban population (Mattingly, 1997; Morley, 1997). 'Major urban' sites were defined as large legal and administrative settlements with a series of features including a grid layout for the street system and organised planning throughout, with public buildings, a forum and a spiritual focus (Wacher, 1974; Burnham and Wacher, 1990; Millett, 1990; Laurence et al., 2011). 'Minor urban' centres displayed some urban aspects, such as evidence for town planning and a market to facilitate local trade (Hingley, 1989; Burnham, 1993; 1995; Millett, 1995; Wilson, 2011). Rural sites were defined as undefended farmsteads, villages, or villa estates with a predominantly agricultural focus (McCarthy, 2013). Depending on their location, rural sites would have exhibited varying economic and socio-cultural dependence on nearby towns (Laurence et al., 2011; White, 2014). However, their agricultural focus still rendered them as rural in character and urbanisation of the countryside to the extent seen in Italy was not apparent in Roman Britain (Laurence, 
2011). Current models on life in the Romano-British countryside consider villa economies as estates managed by landowners, with a peasant population that cultivates the land as tenants or freeholders, living either on the estate or surrounding villages (Taylor, 2001; Mattingly, 2006; McCarthy, 2013; Breeze, 2014).

There is a growing awareness of the difficulty in classifying Romano-British settlements (Mattingly, 1997; Millett, 1999; Burnham et al., 2001; Millett, 2001; Pearce, 2008; Rogers, 2011), and it is important to bear in mind that power in Roman Britain was not exclusively urban, as the elite often resided in the countryside or a town's immediate hinterland (Parkins, 1997; Pitts and Perring, 2006). In addition, not all urban cemeteries would have contained those living and dying exclusively within these large settlements, as many individuals may have been derived from the "urban periphery" (Goodman, 2007:1-2), or represent rural migrants (Griffin and Pitts, 2012; Redfern et al., 2015).

\section{Materials}

Dental caries was recorded in 433 non-adults (aged 1.1-17.0 years) and a total of 6,283 erupted teeth (deciduous $n=2910$; permanent $n=3373$ ) from 15 Romano-British sites dating from the 1st-5th centuries $\mathrm{AD}$ (Table 1, Figure 1). Infants (birth to 1.0 year) were excluded from analysis due to the scarcity of erupted teeth within this age group. The following age categories defined by Lewis (2002) were used: 1.1-2.5 years, 2.6-6.5 years, 6.6-10.5 years, 10.6-14.5 years, 14.6-17.0 years. Age ranges serve to minimise age estimation error, and allow for cross-site comparison while corresponding with developmental milestones (Lampl and Johnston, 1996; Scheuer and Black, 2004; Lewis, 2010).

\section{Methods}

Individuals were aged based on their dental development either through macroscopic assessment or, wherever possible, using radiographs (Moorres et al., 1963a,b). As non-adults were not sexed, male and fe-

TABLE 1. Study sites by settlement date and type

\begin{tabular}{|c|c|c|c|c|c|c|}
\hline Site & Date (AD) & Type & $\begin{array}{l}\text { Total non } \\
\text {-adults }\end{array}$ & $\begin{array}{l}\text { TPR by tooth } \\
\text { count a/p (\%) }\end{array}$ & $\begin{array}{l}\text { CPR by } \\
\text { Individual a/p (\%) }\end{array}$ & Reference \\
\hline $\begin{array}{l}\text { Winchester (North, } \\
\text { West, East) }\end{array}$ & $1-4^{\text {th }}$ century & $\begin{array}{l}\text { Major } \\
\text { Urban }\end{array}$ & 39 & $11 / 559(2.0)$ & $6 / 39(15.4)$ & Ottaway et al. (2012) \\
\hline $\begin{array}{l}\text { Kingsholm, } \\
\text { Gloucester }\end{array}$ & $2-4^{\text {th }}$ century & $\begin{array}{l}\text { Major } \\
\text { Urban }\end{array}$ & 9 & $9 / 135(6.7)$ & $4 / 9(44.4)$ & Hurst (1985), (1986) \\
\hline $\begin{array}{l}\text { Gambier-Parry } \\
\text { Lodge, Gloucester }\end{array}$ & $2-4^{\text {th }}$ century & $\begin{array}{l}\text { Major } \\
\text { Urban }\end{array}$ & 6 & $0 / 76(0.0)$ & $0 / 6(0.0)$ & $\begin{array}{l}\text { Heighway (1980); Mullin } \\
\text { (2006) }\end{array}$ \\
\hline $\begin{array}{l}\text { Trentholme Drive, } \\
\text { York }\end{array}$ & $3-4^{\text {th }}$ century & $\begin{array}{l}\text { Major } \\
\text { Urban }\end{array}$ & 17 & $2 / 262(0.8)$ & $2 / 17(11.8)$ & $\begin{array}{l}\text { Wenham (1968); Ottaway } \\
\text { (2009) }\end{array}$ \\
\hline $\begin{array}{l}\text { Bath Gate, Cirences- } \\
\text { ter }\end{array}$ & $4^{\text {th }}$ century & $\begin{array}{l}\text { Major } \\
\text { Urban }\end{array}$ & 38 & $5 / 483(1.0)$ & $4 / 38$ (10.5) & Viner and Leech (1982) \\
\hline $\begin{array}{l}\text { Butt Road, Colches- } \\
\text { ter }\end{array}$ & $4-5^{\text {th }}$ century & $\begin{array}{l}\text { Major } \\
\text { Urban }\end{array}$ & 80 & $22 / 1209(1.8)$ & $12 / 80(15.0)$ & Crummy and Crossan (1993) \\
\hline $\begin{array}{l}\text { Baldock, Hertford- } \\
\text { shire }\end{array}$ & $2-4^{\text {th }}$ century & $\begin{array}{l}\text { Minor } \\
\text { Urban }\end{array}$ & 25 & $2 / 414(0.5)$ & $2 / 25(8.0)$ & $\begin{array}{l}\text { Stead and Rigby (1986); } \\
\text { Burleigh and Fitzpatrick- } \\
\text { Matthews (2010) }\end{array}$ \\
\hline $\begin{array}{l}\text { Queenford Farm/ } \\
\text { Mill, Oxfordshire }\end{array}$ & $3-4^{\text {th }}$ century & $\begin{array}{l}\text { Minor } \\
\text { Urban }\end{array}$ & 51 & $8 / 729(1.1)$ & $3 / 51(5.9)$ & $\begin{array}{l}\text { Durham and Rowley (1972); } \\
\text { Chambers (1987) }\end{array}$ \\
\hline $\begin{array}{l}\text { Ancaster, Lincoln- } \\
\text { shire }\end{array}$ & $3-4^{\text {th }}$ century & $\begin{array}{l}\text { Minor } \\
\text { Urban }\end{array}$ & 34 & $13 / 480(2.7)$ & $5 / 34(14.7)$ & Todd (1975); Cox (1989) \\
\hline $\begin{array}{l}\text { Great Casterton, } \\
\text { Rutland }\end{array}$ & 3-4th century & $\begin{array}{l}\text { Minor } \\
\text { Urban }\end{array}$ & 27 & $7 / 383(1.8)$ & $4 / 27(14.8)$ & McConnell et al. (2012) \\
\hline $\begin{array}{l}\text { Ashton, Northamp- } \\
\text { tonshire }\end{array}$ & $4^{\text {th }}$ century & $\begin{array}{l}\text { Minor } \\
\text { Urban }\end{array}$ & 17 & $0 / 265(0.0)$ & $0 / 17(0.0)$ & Dix (1983) \\
\hline $\begin{array}{l}\text { Dunstable, Bedford- } \\
\text { shire }\end{array}$ & $3-5^{\text {th }}$ century & $\begin{array}{l}\text { Minor } \\
\text { Urban }\end{array}$ & 12 & $7 / 201(3.5)$ & $4 / 12(33.3)$ & Matthews (1981) \\
\hline $\begin{array}{l}\text { Owslebury, Hamp- } \\
\text { shire }\end{array}$ & $1-4^{\text {th }}$ century & Rural & 3 & $0 / 42(0.0)$ & $0 / 3(0.0)$ & Collis (1968), (1977) \\
\hline $\begin{array}{l}\text { Cannington, Somer- } \\
\text { set }\end{array}$ & $3-4^{\text {th }}$ century & Rural & 69 & $4 / 977(0.4)$ & $3 / 69(4.3)$ & Rahtz et al. (2000) \\
\hline Catsgore, Somerset & $2-5^{\text {th }}$ century & Rural & 1 & $0 / 6(0.0)$ & $0 / 1(0.0)$ & Leech (1982) \\
\hline $\begin{array}{l}\text { Bradley Hill, Som- } \\
\text { erset }\end{array}$ & $4-5^{\text {th }}$ century & Rural & 5 & $0 / 62(0.0)$ & $0 / 5(0.0)$ & Leech et al. (1981) \\
\hline Total non-adults & & & 433 & 90/6283 (1.4) & 49/433 (11.3) & \\
\hline
\end{tabular}




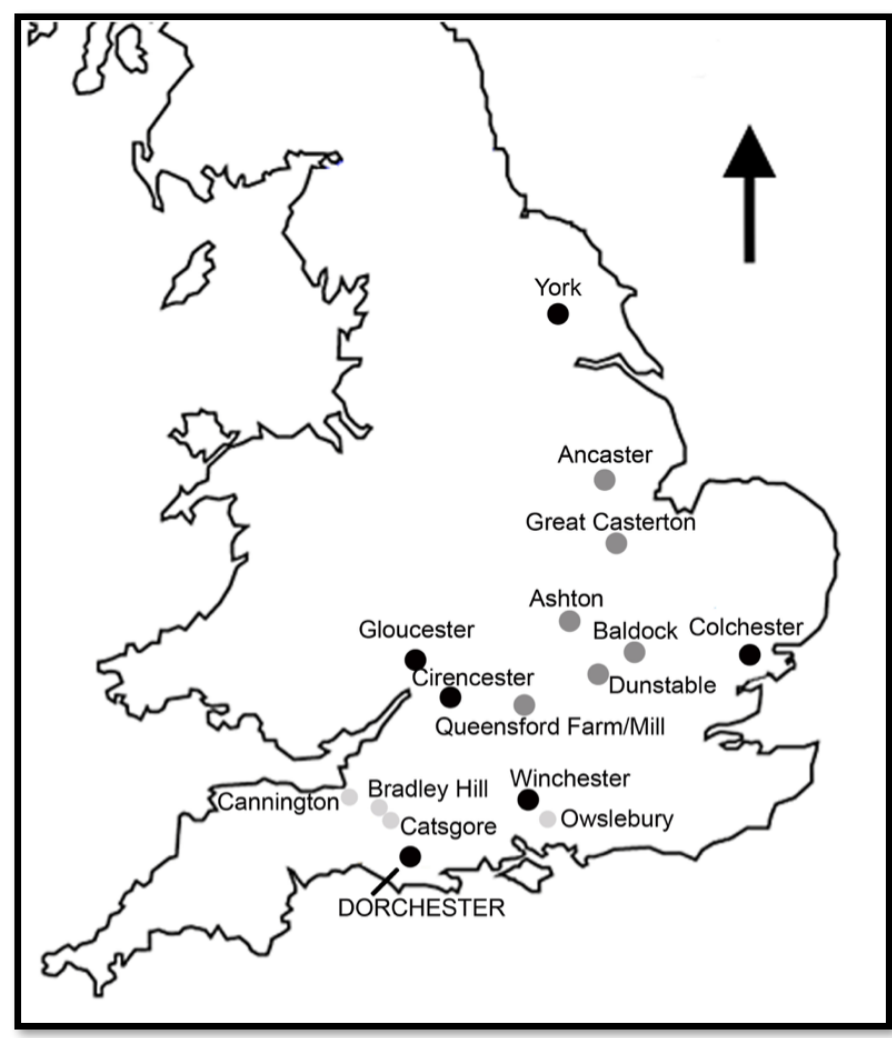

Figure 1. Distribution of study sites (black: major urban, dark grey: minor urban, light grey: rural)

male tooth development stages were averaged. The cut -off point of 17.0 years was assigned when the roots of the third mandibular molar were complete but the apex remained open, giving an average age of 16.9 years old (Smith, 1991). When the apices of the available teeth were closed, an upper age estimate was derived using skeletal maturation and diaphyseal lengths (Ubelaker, 1989; Scheuer and Black, 2000; 2004). Individuals were excluded once the femoral head was fully fused, with completion estimated between 14-17 years in females and 16-19 years for males (Scheuer and Black, 2000; 2004). It is recognised that the cut-off age of 17.0 years reflects a biological rather than chronological age; however, it is based on the oldest, most accurate age estimate we currently have for non-adults (Lampl and Johnston, 1996). It is of course recognized that a biological age of 17.0 years would not necessarily have marked the end of childhood in Roman Britain. The lifecourse of Romano-British children is not fully explored; we therefore cannot use skeletal ages or age groups according to chronological ages that marked transitions in the lifecourse we are yet to define.

Only erupted teeth were included in the analysis, reflecting their susceptibility to dental caries. For teeth within the jaw, eruption was defined as those teeth in occlusion. The identification of loose teeth as erupted involved an assessment of root development stages
(Moorrees et al., 1963a,b) and eruption patterns (Ubelaker, 1989), in addition to any evidence of wear or dental calculus (Buikstra and Ubelaker, 1994). As different teeth have varying degrees of susceptibility to dental caries, they were defined by type: deciduous or permanent, posterior (deciduous and permanent molars, permanent premolars) or anterior (deciduous and permanent incisors and canines) and location (i.e. root or crown). Carious lesion frequencies were reported accordingly. A lesion was recorded macroscopically when it perforated the tooth enamel. Statistical analysis was performed using a Pearson's chi-square test to evaluate the prevalence of lesions between the urban and rural sites, with a confidence limit set at $99.5 \%$ $(p=0.005)$. Percent caries rates are presented as both crude prevalence rates (CPR) for the number of individuals observed and affected, or more precisely as true prevalence rates (TPR) determined by the number of teeth observed over those affected. The caries correction factor advocated by Lukacs (1995) was not applied as antemortem tooth loss is low in non-adult samples and loss of teeth through attrition was unlikely.

Enamel hypoplasia was recorded macroscopically when the tooth enamel was disrupted by circular or linear defects on two or more teeth on opposite sides of the dentition (Goodman and Armelagos, 1985; Goodman and Rose, 1990). This was done to avoid recording defects that may have resulted from localised trauma. The relationship between enamel hypoplasia and caries was quantified by Yule's $Q$.

\section{Entire sample}

\section{RESULTS}

The prevalence of dental caries for each site is listed in Table 1. For all sites and in the deciduous and permanent dentition combined, $11.3 \%(n=49 / 433)$ of individuals displayed caries, with a TPR of $1.4 \%$

( $n=90 / 6283$ teeth). Overall, $2.1 \%$ of posterior teeth were affected ( $\mathrm{n}=79 / 3678$ teeth) compared to only $0.1 \%$ $(n=2 / 2586$ teeth $)$ of the anterior teeth, a significant difference $\left(X^{2}=51.29, p<0.001\right.$, d.f. $\left.=1\right)$. No lesions at the cemento-enamel junction (or 'root caries') were reported. Carious lesions were predominantly found on the occlusal surface of posterior teeth (TPR 1.1\%, $n=39 / 3678$ teeth). Fissure caries accounted for $49.4 \%$ ( $n=39 / 79$ teeth) of lesions in posterior teeth.

When the deciduous and permanent caries rates were compared, TPR was marginally higher in the deciduous dentition at $1.5 \%$ compared to $1.1 \%$, but not significantly so $\left(X^{2}=1.58\right.$, d.f. $\left.=2\right)$ (Table 2$)$.

\section{Inter-settlement comparisons}

Nine carious teeth in the minor urban cohort were derived from the Ancaster toddler with SECC (Bonsall et al., 2015). To prevent skewing of the data, this individual was removed from analysis. The prevalence of 
caries was highest in the major urban sites (CPR $14.8 \%$, TPR $1.8 \%$ ), followed by minor urban (CPR $10.3 \%$, TPR $1.1 \%$ ) and rural settlements (CPR 3.8\%, TPR $0.3 \%$ ). The rural TPR is significantly lower than those reported from the urban settlements $\left(X^{2}=13.66\right.$, $\mathrm{p}<0.005$, d.f. $=2$ ).

Lesion frequency in posterior teeth was significantly lower in the rural sites at TPR $0.6 \%(n=4 / 659$ teeth; $\mathrm{X}^{2}=12.34$, $\mathrm{p}<0.005$, d.f. $=2$ ) compared to both the major and minor urban sites. Lesions in the anterior dentition were only found in two non-adults, both from a major urban site, affecting the deciduous canine in the maxillary dentition of a 2.6-6.5-year old from Kingsholm, Gloucester, and the mandibular deciduous canine of a 6.6-10.5-year old from the northern cemetery at Winchester (see Table 2).

In the deciduous teeth, significantly more lesions were recorded in the major urban cohort $(n=32 / 1075$ teeth) at TPR 3.0\% $\left(\mathrm{X}^{2}=27.03, \mathrm{p}<0.001\right.$, d.f. $\left.=2\right)$. Whereas no significant differences were observed for caries in the permanent teeth (see Table 2).

Interproximal caries affecting the crown surface, either mesially or distally, was observed in 29 posterior teeth or $1.0 \%$ of the total sample ( $n=29 / 3019$ teeth), but only in the major and minor urban sites with a revised prevalence rate of $38.7 \%$ ( $n=29 / 75$ teeth). Again, buccal caries was only observed in these urban cohorts with a prevalence of $10.7 \%(n=8 / 75$ teeth).

Age differences

The prevalence of caries increased with age, albeit with a slight decrease in the 10.6-14.5 year age group (CPR $16.7 \%$, TPR $1.3 \%$ ), probably as a result of the shedding of the primary dentition. Caries was not apparent until 10.6 years in the rural sample, whereas lesions were observed in the youngest cohort (1.1-2.5 years) in the major urban sample. In the 6.6-10.5-year cohort, the frequency of carious lesions was statistically higher in the major urban sample at TPR 3.7\% $\left(n=20 / 539\right.$ teeth; $X^{2}=11.36, p<0.005$, d.f. $\left.=2\right)$ compared to both the minor urban and rural sites. Out of the total of 20 carious teeth within this major urban group, 17 (85.0\%) were deciduous molars (Table 3).

\section{Stress and caries}

In the major urban group, $11.4 \%$ of teeth $(n=309 / 2700$ teeth) had dental enamel defects, compared to $9.6 \%(n=236 / 2460$ teeth $)$ in the minor urban cohort, and $4.5 \%$ ( $n=49 / 1087$ teeth) in the rural sample. The rural rate was significantly lower than those from both urban contexts $\left(X^{2}=43.66, p<0.001\right.$, d.f. $\left.=2\right)$. The higher rates of enamel hypoplasia observed in major urban non-adults (TPR 11.4\%) also matched the elevated rates of caries in these settlements. Overall, $39.6 \%(n=19 / 48)$ of the children with caries also had enamel hypoplasia. The Yule's Q statistic of 0.75 indicates that a moderate to strong relationship between the two conditions existed. This co-occurrence was highest in major urban sites at $5.8 \%(\mathrm{n}=11 / 189)$ and lowest in rural children at $1.3 \%(\mathrm{n}=1 / 78)$, although these differences were not significant $\left(X^{2}=3.26\right.$, d.f. $\left.=2\right)$ (Table 4).

TABLE 2. Carious lesion frequencies by tooth type and individual

\begin{tabular}{|c|c|c|c|c|c|c|c|c|c|}
\hline & & \multicolumn{2}{|c|}{ Major Urban } & \multicolumn{2}{|c|}{ Minor Urban } & \multicolumn{2}{|l|}{ Rural } & \multicolumn{2}{|l|}{ Total } \\
\hline & & Tth & Ind & Tth & Ind & Tth & Ind & Tth & Ind \\
\hline \multirow[t]{2}{*}{ Total } & $a / p$ & $49 / 2724$ & $28 / 189$ & $\begin{array}{l}28 / 2453^{*} \\
(37 / 2472)\end{array}$ & $\begin{array}{l}17 / 165^{*} \\
(18 / 166)\end{array}$ & $4 / 1087$ & $3 / 78$ & $\begin{array}{l}81 / 6264^{*} \\
(90 / 6283)\end{array}$ & $48 / 432 *(49 / 433)$ \\
\hline & $\%$ & 1.8 & 14.8 & $1.5^{*}(1.5)$ & $10.3^{*}(10.4)$ & 0.3 & 3.8 & $1.3^{*}(1.4)$ & $11.1^{*}(11.3)$ \\
\hline \multirow{2}{*}{$\begin{array}{l}\text { Deciduous } \\
\text { teeth }\end{array}$} & $a / p$ & $32 / 1075$ & $14 / 125$ & $10 / 1335$ & $7 / 127$ & $1 / 481$ & $1 / 54$ & $43 / 2891$ & $22 / 306$ \\
\hline & $\%$ & 3.0 & 11.2 & 0.7 & 5.6 & 0.2 & 1.9 & 1.5 & 7.2 \\
\hline \multirow{2}{*}{$\begin{array}{l}\text { Permanent } \\
\text { teeth }\end{array}$} & $\mathrm{a} / \mathrm{p}$ & $17 / 1649$ & $14 / 124$ & $18 / 1118$ & $10 / 86$ & $3 / 606$ & $2 / 43$ & $38 / 3373$ & $26 / 253$ \\
\hline & $\%$ & 1.0 & 11.3 & 1.6 & 11.6 & 0.5 & 4.7 & 1.1 & 10.3 \\
\hline \multirow[t]{2}{*}{ Anterior teeth } & $\mathrm{a} / \mathrm{p}$ & $2 / 1100$ & $2 / 171$ & $0 / 1058$ & $0 / 152$ & $0 / 428$ & $0 / 69$ & $2 / 2586$ & $2 / 392$ \\
\hline & $\%$ & 0.2 & 1.2 & 0 & 0 & 0 & 0 & 0.08 & 0.5 \\
\hline \multirow{2}{*}{$\begin{array}{l}\text { Posterior } \\
\text { teeth }\end{array}$} & $\mathrm{a} / \mathrm{p}$ & $47 / 1624$ & $28 / 185$ & 28/1395 & $17 / 164$ & $4 / 659$ & $3 / 78$ & $79 / 3678$ & $48 / 427$ \\
\hline & $\%$ & 2.9 & 15.1 & 2.0 & 10.4 & 0.6 & 3.8 & 2.1 & 11.2 \\
\hline
\end{tabular}

Tth = tooth count; Ind=individual count; $a / p$ = number affected/number present; *corrected rates for the Ancaster child with SECC, uncorrected rates in brackets 
TABLE 3. Carious lesion frequencies by age group and site type

\begin{tabular}{llcccccccc}
\hline \multirow{2}{*}{ Age (years) } & & \multicolumn{2}{c}{ Major Urban } & \multicolumn{2}{c}{ Minor Urban } & \multicolumn{2}{c}{ Rural } & \multicolumn{2}{c}{ Total } \\
& & Tth & Ind & Tth & Ind & Tth & Ind & Tth & Ind \\
\hline $\mathbf{1 . 1 - 2 . 5}$ & $\mathrm{a} / \mathrm{p}$ & $1 / 394$ & $1 / 38$ & $0 / 571$ & $0 / 49$ & $0 / 193$ & $0 / 21$ & $\mathbf{1 / 1 1 5 8}$ & $\mathbf{1 / 1 0 8}$ \\
& $\%$ & 0.3 & 2.6 & 0.0 & 0.0 & 0.0 & 0.0 & $\mathbf{0 . 1}$ & $\mathbf{0 . 9}$ \\
$\mathbf{2} .6-6.5$ & $\mathrm{a} / \mathrm{p}$ & $12 / 555$ & $7 / 50$ & $7 / 774$ & $4 / 56$ & $0 / 254$ & $0 / 22$ & $\mathbf{1 9 / 1 5 8 3}$ & $\mathbf{1 1 / 1 2 8}$ \\
& $\%$ & 2.2 & 14.0 & 0.9 & 7.1 & 0.0 & 0.0 & $\mathbf{1 . 2}$ & $\mathbf{8 . 6}$ \\
$\mathbf{6 . 6 - 1 0 . 5}$ & $\mathrm{a} / \mathrm{p}$ & $20 / 539$ & $8 / 35$ & $4 / 393$ & $4 / 27$ & $0 / 112$ & $0 / 8$ & $\mathbf{2 4 / 1 0 4 4}$ & $\mathbf{1 2 / 7 0}$ \\
& $\%$ & 3.7 & 22.9 & 1.0 & 14.8 & 0.0 & 0.0 & $\mathbf{2 . 3}$ & $\mathbf{1 7 . 1}$ \\
$\mathbf{1 0 . 6 - 1 4 . 5}$ & $\mathrm{a} / \mathrm{p}$ & $11 / 883$ & $8 / 44$ & $11 / 520$ & $5 / 25$ & $1 / 315$ & $1 / 15$ & $\mathbf{2 3 / 1 7 1 8}$ & $\mathbf{1 4 / 8 4}$ \\
& $\%$ & 1.3 & 18.2 & 2.1 & 20.0 & 0.3 & 6.7 & $\mathbf{1 . 3}$ & $\mathbf{1 6 . 7}$ \\
$\mathbf{1 4 . 6 - 1 7 . 0}$ & $\mathrm{a} / \mathrm{p}$ & $5 / 213$ & $4 / 20$ & $6 / 195$ & $4 / 8$ & $3 / 351$ & $2 / 12$ & $\mathbf{1 4 / 7 5 9}$ & $\mathbf{1 0} / \mathbf{4 0}$ \\
& $\%$ & 2.4 & 20.0 & 3.1 & 50.0 & 0.9 & 16.7 & $\mathbf{1 . 8}$ & $\mathbf{2 5 . 0}$ \\
\hline
\end{tabular}

Tth = tooth count; Ind=individual count; $a / p=$ number affected/number present

TABLE 4. Prevalence rates of enamel hypoplasia and co-morbidity

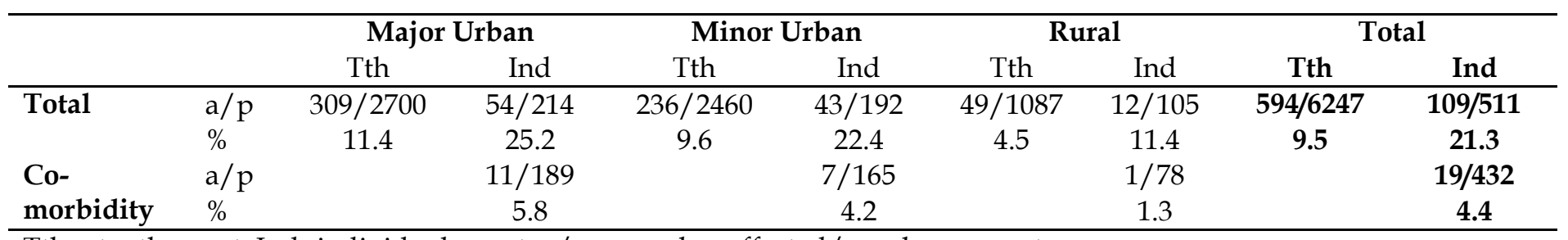

Tth = tooth count; Ind=individual count; $a / p=$ number affected/number present

\section{DISCUSSION}

This study provides the first large-scale examination of carious lesion frequencies in non-adults from urban and rural settlements in Roman Britain. Dental caries is age-progressive and multifactorial, but can provide valuable insights into the cultural habits that affected non-adult diet, particularly where the characteristics of eating and drinking in childhood across Roman Britain are still largely unknown. This study is limited by the scarcity of skeletal and dental material from rural sites, a common problem within RomanoBritish bioarchaeology, and due to limited sample sizes it was also not possible to analyse variations in diet over time.

However, caries affected $11.3 \%$ of the RomanoBritish children, or $1.4 \%$ of all erupted teeth. Lesions were more frequent in children from major urban sites, where $14.8 \%$ of non-adults presented with caries. This is substantially higher than the non-adult rate reported at the Dorchester civitas (CPR 3.6\%, Lewis pers. comm.), which is thought to represent a major urban settlement. Instead, the Dorchester rates are more comparable to the rural pattern (CPR 3.8\%) (see
Table 2, Table 5). The major urban TPR of $1.8 \%$ is, however, similar to that reported from the Lankhills cemetery for the Winchester civitas (TPR 1.7\%) (Clough and Boyle, 2010).

When the deciduous teeth were examined, lesions were statistically more frequent in the major urban sample (TPR 3.0\%), the only cohort to show individuals with caries in the anterior deciduous dentition. Higher rates of lesions in the deciduous compared to permanent dentition might be expected due to reduced enamel hardness and longer exposure to the oral environment (Hunter et al., 2000; Halcrow et al., 2013), although soft and carbohydrate-rich weaning foods further elevate early childhood caries (Temkin, 1991; Garnsey, 1999). Hence, the greater frequencies of deciduous caries in the major urban group suggest a prolonged exposure to cariogenic foods during early childhood (Veerkamp and Weerheijm, 1995; Berkowitz, 2003; Freeman and Stevens, 2008), while the presence of anterior deciduous caries may hint at the use of pacifiers (Azevedo et al., 2005). The significantly lower rate of deciduous caries in the rural settlements suggests a different early childhood diet or 
TABLE 5. Previously reported caries rates in Romano-British non-adults

\begin{tabular}{|c|c|c|c|c|c|}
\hline Study & Site and context & Date (AD) & $\begin{array}{l}\text { CPR } \\
(\%)\end{array}$ & TPR (\%) & Comments \\
\hline $\begin{array}{l}\text { Moore and Corbett } \\
\text { (1973) }\end{array}$ & $\begin{array}{l}\text { Various unknown } \\
\text { Major urban, mili- } \\
\text { tary }\end{array}$ & $1^{\text {st-5 }} 5^{\text {th }}$ century & & 4.2 & Deciduous teeth \\
\hline $\begin{array}{l}\text { O'Sullivan et al. } \\
\text { (1993) }\end{array}$ & $\begin{array}{l}\text { Various unknown } \\
\text { Not stated }\end{array}$ & $1^{\text {st }} 5^{\text {th }}$ century & & 16.0 & Deciduous molars \\
\hline Redfern et al. (2012) & $\begin{array}{l}\text { Various (Dorset) } \\
\text { Major urban, rural }\end{array}$ & $1^{\text {st }} 5^{\text {th }}$ century & & $0.3 / 1.5$ & $\begin{array}{l}\text { Deciduous/ } \\
\text { permanent teeth }\end{array}$ \\
\hline Lewis (pers. comm.) & $\begin{array}{l}\text { Poundbury Camp } \\
\text { Dorchester Civitas }\end{array}$ & $3^{\text {rd }}-5^{\text {th }}$ century & 3.6 & $0.7 / 0.7$ & $\begin{array}{l}\text { Deciduous/ } \\
\text { permanent teeth }\end{array}$ \\
\hline $\begin{array}{l}\text { Clough and Boyle } \\
\text { (2010) }\end{array}$ & $\begin{array}{l}\text { Lankhills } \\
\text { Winchester Civitas }\end{array}$ & $4^{\text {th }}$ century & & 1.7 & $\begin{array}{l}\text { Deciduous and } \\
\text { permanent teeth }\end{array}$ \\
\hline Caffell (2007) & $\begin{array}{l}\text { Horncastle, Lincoln- } \\
\text { shire, Fort/minor } \\
\text { urban }\end{array}$ & $4^{\text {th }}$ century & & $12.5 / 0.0$ & $\begin{array}{l}\text { Deciduous/ } \\
\text { permanent teeth }\end{array}$ \\
\hline
\end{tabular}

food processing techniques. Fewer carious lesions in the rural cohort may suggest that this part of the population was restricted in its consumption of agricultural products, which are high in carbohydrates. Perhaps this reflects the primary role of rural inhabitants in this period, who were expected to produce a surplus to provide for urban dwellers, the army, and the elite (de la Bédoyère 1993, 86; Jones 1996, 208; MacMullen 1987; Whittaker and Garnsey 1997), where rural families would have been hesitant to consume their primary source of income. In turn, rural weaning foods may have been chosen that were less economically important and also less cariogenic. Differences in the archaeobotanical record between rural sites, particularly in the southwest where the sample sites of the current study are located, and urban settlements across Roman Britain were observed by van der Veen and colleagues (2008), and strengthen the argument for biased food allocation between producer and consumer. A diet high in grit, with hard and abrasive fibrous foods or contaminants may have also been consumed in rural areas, limiting dental caries development (Duray, 1992; Moynihan, 2000). Further research into dental wear in the urban and rural groups may help elucidate this pattern.

While it is important to compare the results from this study with those that have gone before, this is challenging. Many of the studies that have discussed caries rates in Romano-British nonadults have very small sample sizes, and merged data without specifying which sites they included (Table 5). However, data for carious lesion frequency in non-adults is available for Rome itself.
Killgrove (2010) reported true prevalence rates for 0-10 year olds, and 11-20 year olds. At Casal Bertone, a cemetery located close to the walls of the city of Rome, caries prevalence rates were $3.2 \%$ (010 year olds) and $2.9 \%$ (11-20 year olds), compared to $2.2 \%$ ( $n=33 / 1488$ teeth in 1.1-10.5 year olds) and $1.5 \%(\mathrm{n}=16 / 1096$ teeth in 10.6-17.0 year olds) in the major urban cohort of the current study. Lesions were less frequent at the cemetery at Castellia Europarco which was located in an agricultural area of the suburbs of Rome. Just as in this study, no dental caries was reported in children under 10 years old; however, the sample was small $(n=2 / 121$ teeth) (Killgrove 2010). Although we cannot make inferences on the specific foods eaten in Rome and the major urban towns of Roman Britain from this comparison, dental disease rates from both locations highlight the pertinent differences in oral health between residents of the towns and country at the centre and the fringes of the Empire. Prowse and colleagues (2008) reported a TPR of 3.8\% for carious lesions in the deciduous teeth of 1-12 year olds from the necropolis at Isola Sacra at urban Portus. Although the deciduous caries rates for major urban settlements (3.0\%) in the current study are significantly higher than elsewhere in Roman Britain, it is below that of children living in Italy, even outside of Rome. Additional data for child caries rates comes from Kellis II in Egypt, where Shukrum and Molto (2009) reported a TPR of 8.9\% for deciduous teeth and TPR $3.8 \%$ for the permanent dentition, again substantially higher than seen in the British province. Overall, refined carbohydrates and a more fortified diet may have been 
more readily available to major urban residents in Roman Britain, compared to those living in the countryside. Yet, access to rich foods was more restricted than in Rome, the Italian urban centres and other provinces closer to the centre of the Empire. However, we also have to assume that genetic and geographic factors, such as immunity and fluoride exposure may have influenced dental caries susceptibility between these different populations.

Although the exact pathophysiology of a relationship between enamel hypoplasia and carious lesion development remains to be explored, a total of $39.6 \%$ of children with carious lesions also displayed dental enamel hypoplasia. The result was anticipated, and is consistent with the cariespromoting function of stress. Stress may have elevated salivary cortisol levels, which in turn suppressed salivary IgA and enabled cariogenic bacteria to spread (Boyce et al., 2010). Not only will these children have experienced a greater spread of cariogenic bacteria, but the quality of hypoplastic teeth would have exacerbated this effect. In the affected children, bacteria adhere to the site of the defect, and the thinned or defective enamel is more acid soluble, both allowing for dental caries to progress quicker (Hong et al., 2009). Co-occurrence of caries and enamel defects was more frequent in the urban cohorts. More bacteria in the oral cavity, and thinned enamel as a result of non-specific stress may have contributed to the progression of caries in those children. Since hypoplastic enamel defects were more frequent in the major urban cohort than in the rural children, both diet and non-specific stress may have contributed to the significant differences in carious lesion frequencies. This would suggest that higher status of the major urban children was not necessarily a given.

The youngest individual reported with carious lesions was a 1.1-2.5-year old from Butt Road, Colchester with occlusal carious lesions on the deciduous maxillary second molar. The rise in caries TPRs from the youngest age group may reflect the timing of colonisation of the oral cavity with S. mutans. Carious lesions usually appear between 13-16 months after initial colonisation (Kawashita et al., 2011), suggesting the children in this study were affected at around one year of age. However, the administration of cariogenic foods and feeding habits may have occurred earlier, for instance between 6-12 months when infants start to sit up, develop better chewing and tasting mechanisms, and are eventually able to self-feed (Sheridan, 1991; Sellen, 2001; 2007; Carruth and Skinner, 2002; Delaney and Arvedson, 2008). Neither human breastmilk nor cow's milk are very cariogenic, but their caries-promoting properties are significantly increased when the infant is fed supplementary foods rich in carbohydrates such as fruits and honey (Moynihan, 2000; Azevedo et al., 2005; Kawashita et al., 2011). Today, S. mutans is mainly transmitted from the primary caregiver to the infant as soon as tooth surfaces have erupted (Gussy et al., 2006). In Rome, early child care was not only provided by the mother, but also by a nutrix or paedagogus among richer families (McWilliam, 2013), or by neighbours, friends and relatives for working women (Rawson, 2003a; Golden, 2011). It is likely similar practices were in place in Britain. For example, caries rates in Romano-British females are reported as $5.4 \%$ at Cannington (Brothwell et al., 2000), 3.9\% at Butt Road, Colchester (PinterBellows, 1993), and 5.4\% at Bath Gate, Cirencester (Wells, 1982), higher than those observed in the non-adults from the same sites (TPRs of $0.4 \%, 1.8 \%$ and $1.0 \%$ respectively). The mechanism of $S . m u$ tans transmission may show that Romano-British care givers pre-chewed or tasted their infants' food, and shared utensils with them when administering food or drink (Fildes, 1986). Historical evidence for pre-mastication refers to it as a practice to be avoided (Bradley, 1986; Temkin, 1991), which indicates that it might have indeed occurred, and probably had an influence on the transmission of oral infections from caregiver to child.

Lesion frequencies were higher in major urban and minor urban children from 10.6-17.0 years, at almost four times the rate reported for the rural sites. It is possible that this pattern is reflecting a richer diet of fortified foods for these adolescents. The fact that the majority of carious lesions in both the major urban and minor urban samples were interproximal and occlusal further attests to a softer and more refined diet (Vodanović et al., 2005). There is archaeological evidence for the fine milling of cereals into white flour (Cool, 2006; Alcock, 2010) and following a Roman diet, refined sugar may have been accessed in the form of honey and syrups (Moore and Corbett, 1973; Bowman and Thomas, 1994; Cool, 2006; Carreck, 2008; Crane, 2013). Honey has antibacterial properties which inhibit $S$. mutans growth, but whether honey is primarily cariogenic or cario-protective is debatable (Bogdanov et al., 2008; Nassar et al., 2012). However, it would have been the main sweetener in this time period and therefore frequently consumed. Grape syrup known as defrutum, sapa or caroenum was made in Spain or southern Gaul and was shipped to Britain in distinctive amphorae (Cool, 
2006). Evidence for these amphorae in Britain is scarce and dates mainly to the 1 st and 2 nd centuries $\mathrm{AD}$. These syrups were therefore either imported in different vessels in the later centuries, became even more difficult to get hold of or, alternatively, ceased to be available in Roman Britain (Sealey and Davies, 1984; Sealey and Tyers, 1989; Monfort, 1998). However, defrutum could be made from boiling down any fruit juice in lead vessels, and would therefore have been widely available across Roman Britain (Farwell and Molleson, 1993; Roberts and Cox, 2003). In summary, carious lesion frequencies in children aged older than 10.6 years attest to dietary differences between those living in the towns and country, probably linked with the availability of more refined and softer foods in the urban centres.

\section{CONCLUSIONS}

This research has demonstrated the value of reporting carious lesion frequency in non-adults. Its use is further increased by considering the location and type of carious lesions, and the presence of early childhood stress. Higher rates of dental disease in urban environments suggest differences in diet between children in the countryside and the towns of Britannia. Elevated stress, measured as the prevalence of enamel hypoplasia, in the children growing up in urban settlements was accompanied by higher carious lesion frequency. However, we cannot currently estimate how exact the relationship between stress and enamel defects is to the incidence and severity of dental caries. Carious lesions in the deciduous dentition allow for inferences to be made on weaning and feeding practices that promote dental decay, such as the sharing of utensils and food between caregiver and child. The lower frequency of carious lesions in the rural sample suggests a simpler diet consumed by these children, possibly as a result of biased food allocation in response to economic pressures. Urban populations may have had more access to processed and sweetened foodstuffs whereby refined carbohydrates were more readily available.

\section{ACKNOWLEDGMENTS}

This research was funded by an AHRC PhD Studentship. We thank the curators who provided access to the skeletal collections for this project: Robert Kruszynski, Natural History Museum London; Keith Fitzpatrick-Matthews, North Hertfordshire District Council Museums Service; Simon Mays, English Heritage; Christiane Jeuckens, Oxfordshire Museums Service; Jo Buckberry, Biologi- cal Anthropology Research Centre; Steve Minnitt, Somerset Heritage Centre; David Allen, Hampshire Arts and Museums Service; Sarah Wilson, Peterborough Museum; Helen Rees, Winchester Museum Service; Lorraine Cornwell, Rutland County Museum; Alison Brooks and Heather Dawson, Corinium Museum; Paul Sealey, Colchester and Ipswich Museums and Timothy Vickers, Luton Culture. The authors thanks the anonymous reviewers and editor for their constructive comments which have greatly improved an earlier draft of this paper.

\section{LITERATURE CITED}

Afroughi S, Faghihzadeh S, Khaledi MJ, Motlagh MG. 2010. Dental caries analysis in 3-5 years old children: a spatial modelling. Arch Oral Biol 55:374-378.

Aligne C, Moss M, Auinger P, Weitzman M. 2003. Association of pediatric dental caries with passive smoking. JAMA 289:1258-1264.

Alcock JP. 2010. Food in Roman Britain. Stroud: The History Press.

Azevedo TDPL, Bezerra ACB, de Toleda OA. 2005. Feeding habits and severe early childhood caries in Brazilian preschool children. Pediatr Dent 27:28-33.

Bagain Z, Newman L, Hyde N. 2004. How serious are oral infections?. J Laryngol Otol 118:561-565.

Bennion E. 1986. Antique Dental Instruments. London: Sotheby's.

Berkowitz RB. 2003. Causes, treatment and prevention of early childhood caries: a microbiologic perspective. J Can Dent Assoc 69:304-307.

Bogdanov S, Jurendic T, Sieber R, Gallmann P. 2008. Honey for nutrition and health: a review. J Am Coll Nutr 27:677-689.

Bonfiglioli B, Brasili P and Belcastro MG. 2003. Dento-alveolar lesions and nutritional habits of a Roman Imperial age population (1st-4th c. AD): Quadrella (Molise, Italy). HOMO 54:36-56. Bonsall L, Ogden AR, Mays S. 2015. A case of early childhood caries (ECC) from late Roman Ancaster, England. Int J Osteoarch. DOI: 10.1002/ oa.2441.

Bowman AK, Thomas JD. 1994. The Vindolanda Writing Tablets (Taulae Vindolandenses II). London: British Museum Press.

Boyce WT, Den Besten PK, Stamperdahl J, Zhan L, Jiang Y, Adler NE, Featherstone JD. 2010. Social inequalities in childhood dental caries: the convergent roles of stress, bacteria and disadvantage. Soc Sci Med 71:1644-1652.

Bradley KR. 1984. Slaves and masters in the Roman 
Empire - a study in social control. Oxford: Oxford University Press.

Bradley KR. 1986. Wet-nursing at Rome: a study in social relations. In: Rawson B, editor. The family in ancient Rome - new perspectives. London: Routledge. p 201-229.

Bradley KR. 1991. Discovering the Roman family studies in Roman social history. Oxford: Oxford University Press.

Bradley K. 1994. Slavery and society at Rome - key themes in ancient history. Cambridge: Cambridge University Press.

Bradley K. 2005. The Roman child in sickness and in health. In: George M, editor. The Roman family in the Empire. Oxford: Oxford University Press. p 67-92.

Breeze DJ (ed.). 2014. The Impact of Rome on the British Countryside. A Conference Organised by the Royal Archaeological Institute, Chester, 1113 October 2013. London: Royal Archaeological Institute Supplementary Publication.

Buikstra JE, Ubelaker DH (eds.). 1994. Standards for data collection from human skeletal remains. Fayetteville: Arkansas Archaeological Survey Research Series Number 44.

Burleigh GR, Fitzpatrick-Matthews KJ. 2010. Excavations at Baldock, Hertfordshire, 1978-1994 Volume 1 - An Iron Age and Romano-British cemetery at Wallington Road. Hitchin: North Hertfordshire District Council Museums Service and North Hertfordshire Archaeological Society.

Burnham BC. 1993. The small towns of Roman Britain - the last fifty years. In Greep SJ, editor. Roman towns: The Wheeler inheritance. York: CBA Research Report 93. p 99-110.

Burnham BC. 1995. Small towns: the British perspective. In: Brown AE, ed. Roman small towns in eastern England and beyond. Oxford: Oxbow Monograph 52. p 7-18.

Burnham BC, Wacher J. 1990. The small towns of Roman Britain. London: Batsford.

Burnham BC, Collis J, Dobinson C, Haselgrove C, Jones M. 2001. Themes for urban research, c 100 BC to AD 200. In: James S, Millett M, eds. Britons and Romans: advancing an archaeological agenda. York: CBA Research Report 125. p 6776.

Byun R, Nadkarni MA, Chhour K, Martin FE, Jacques NA, Hunter N. 2004. Quantitative analysis of diverse Lactobacillus species present in advanced dental caries. J Clin Microbiol 42:7, 3128-3136.

Caffell A, Holst M. 2007. Osteological Analysis,
Horncastle, East Lincolnshire. York: Unpublished Skeletal Report by York Osteoarchaeology. Commissioned by Lindsey Archaeological Services.

Carreck NL. 2008. Are honey bees (Apis mellifera L.) native to the British Isles?. J Apic Res 47(4): 318-322.

Carruth BR, Skinner JD. 2002. Feeding behaviours and other motor development in healthy children (2-24 months). J Am Coll Nutr 21: 88-96.

Chambers RA. 1987. The late and sub-Roman cemetery at Queenford Farm, Dorchester-onThames, Oxon. Oxoniensia 52: 35-70.

Chenery C, Müldner G, Evans J, Eckardt H, Lewis M. 2009. Strontium and stable isotope evidence for diet and mobility in Roman Gloucester, UK. J Archaeol Sci 37: 150-163.

Cheung C, Schroeder H, Hedges REM. 2012. Diet, social differentiation and social change in Roman Britain: new isotopic evidence from Gloucestershire. Archaeol Anthropol Sci 4: 6173.

Clarke M, Locker D, Berall G, Pencharz P, Kenny DJ, Judd P. 2006. Malnourishment in a population of young children with severe early childhood caries. Pedr Dent 28: 2524-259.

Clough S, Boyle A. 2010. Inhumations and disarticulated human bone. In: Booth P, Simmonds A, Boyle A, Clough S, Cool HEM, Poore D. The late Roman cemetery at Lankhills, Winchester - excavations 2000-2005. Oxford: Oxford Archaeology. p 339-399.

Collis JR. 1968. Excavations at Owslebury, Hampshire: an interim report. Ant J 48: 18-31.

Collis J. 1977. Owslebury (Hants) and the problem of burials on rural settlements. In: Reece R, ed. Burial in the Roman World. York: CBA Research Report 22. p 26-34.

Cook DC, Buikstra JE. 1979. Health and differential survival in prehistoric populations: prenatal dental defects. Am J Phys Anthropol 51: 649664.

Cool HEM. 2006. Eating and drinking in Roman Britain. Cambridge: Cambridge University Press.

Cox M. 1989. The human bones from Ancaster. London: Unpublished Ancient Monuments Laboratory Report 93/89.

Craig OE, Biazzo M, O'Connell T, Garnsey P, Martinez-Labarga C, Lelli R, Salvadei L, Tartaglia G, Nava A, Reno L, Fiammenghi A, Rickards O, Bondioli L. 2009. Stable isotopic evidence for diet at the Imperial Roman coastal site of Velia (1st and 2nd centuries AD) in Southern Italy. 
Am J Phys Anthropol 139, 572-583.

Crane EE. 2013. The world history of beekeeping and honey hunting. London: Routledge.

Crummy N, Crossan C. 1993. Excavations at Butt Road Cemetery, 1976-9, 1986 and 1989. In: Crummy N, Crummy P, Crossan C. Colchester Archaeological Report 9: Excavations of Roman and later cemeteries, churches and monastic sites in Colchester, 1971-88. Colchester: Colchester Archaeological Trust. p 4-163.

Cummings C. 2009. Meat consumption in Roman Britain: the evidence from stable isotopes. In: Driessen M, Heeren S, Hendriks J, Kemmers F, Visser R, eds. TRAC 2008: Proceedings of the eighteenth annual Theoretical Roman Archaeology Conference, Oxford. Oxford: Oxbow Books. p 73-83.

Dasen V. 2011. Childbirth and infancy in Greek and Roman Antiquity. In: Rawson B, ed. A companion to families in the Greek and Roman worlds. Chichester: Wiley-Blackwell. p 291-314.

de la Bédoyère G. 1993. English Heritage book of Roman villas and the countryside. London: B T Batsford/English Heritage.

Delaney AL, Arvedson JC. 2008. Development of swallowing and feeding: prenatal through first year of life. Dev Dis Res Rev 14: 105-117.

Dix B. 1983. Ashton Roman town. SMidlA 13: 1820.

Dobney K. 2001. A place at the table: the role of vertebrate zooarchaeology within a Roman research agenda for Britain. In: James S, Millett M, eds. Britons and Romans: advancing an archaeological agenda. York: CBA Research Report 125. p 36-45.

Duray SM. 1990. Deciduous enamel defects and caries susceptibility in a prehistoric Ohio population. Am J Phys Anthropol 81: 27-34.

Duray SM. 1992. Enamel defects and caries etiology: an historical perspective. In: Goodman $\mathrm{AH}$, Capasso LL, eds. Recent contributions to the study of enamel developmental defects. J Paleopathol Monographic Publications 2. p 307-320.

Durham B, Rowley T. 1972. A cemetery site at Queensford Mill, Dorchester. Oxoniensia 37: 3238.

Eckardt H. 1999. The Colchester 'child's grave'. Britannia 30: 57-90.

Faith R. 1997. The English peasantry and the growth of lordship. London: Leicester University Press.

Farwell DE, Molleson TI. 1993. Poundbury Volume 2 - The Cemeteries. Dorchester: Dorset Natural History and Archaeological Society Monograph
Series 11.

Fejerskov O, Bilde PG, Bizzarro M, Connelly JN, Thomsen JS, Nyvad B. 2012. Dental caries in Rome, 50-100 AD. Caries Res 46: 467-473.

Fewtrell MS, Morgan JB, Duggan C, Gunnlaugsson G, Hibberd PL, Lucas A, Kleinman RE. 2007. Optimal duration of exclusive breastfeeding: what is the evidence to support current recommendations? Am J Clin Nutr 85(2): 635-638.

Fildes V. 1981. The early history of the infant feeding bottle - I. Nurs Times 15: 128-129.

Fildes VA. 1986. Breasts, bottles and babies - a history of infant feeding. Edinburgh: Edinburgh University Press.

Fildes V. 1988. Wet nursing - a history from Antiquity to the Present. Oxford: Basil Blackwell.

Fischer K. 1987. Nochmals ubuppa und tit(t)ina. Philologus 131(1-2): 156-157.

Fischman SL. 1997. The history of oral hygiene products: how far have we come in 6000 years? J Periodontol 2000 15: 7-14.

Freeman R, Stevens A. 2008. Nursing caries and buying time: an emerging theory of prolonged bottle feeding. Community Dent Oral Epidemiol 36: 425-433.

Fuller BT, Molleson TI, Harris DA, Gilmour LT, Hedges REM. 2006. Isotopic evidence for breastfeeding and possible adult dietary differences from Late/Sub-Roman Britain. A J Phys Anthropol 129: 45-54.

Garcin V, Velemínský P, Trefný P, Alduc-Le Bagousse A, Lefebvre A, Bruzek J. 2010. Dental health and lifestyle in four early mediaeval juvenile populations: comparisons between urban and rural individuals, and between coastal and inland settlements. HOMO 61(6): 421-439.

Garnsey P. 1991. Child rearing in Ancient Italy. In: Kertzer DI and Saller RP, eds. The family in Italy - from Antiquity to the Present. New Haven: Yale University Press. p 48-65.

Garnsey P. 1999. Food and society in Classical Antiquity. Cambridge: Cambridge University Press.

Garnsey P, Saller R. 1987. The Roman Empire economy, society and culture. Berkeley: University of California Press.

Golden M. 2011. Other people's children. In: Rawson B, ed. A companion to families in the Greek and Roman worlds. Chichester: WileyBlackwell. p 262-275.

Goodman PJ. 2007. The Roman city and its periphery - From Rome to Gaul. London: Routledge. Goodman AH, Armelagos GJ. 1985. Factors affect- 
ing the distribution of enamel hypoplasias within the human permanent dentition. Am J Phys Anthropol 68: 479-493.

Goodman AH, Rose JC. 1990. Assessment of systemic physiological perturbations from dental enamel hypoplasias and associated histological structures. Am J Phys Anthropol 33 (S11), 59110.

Griffin R, Pitts M. 2011. Inequality at late Roman Baldock, UK - the impact of social factors on health and diet. J Anthropol Res 67: 533-556.

Grocock C, Grainger S. 2006. Apicius. Totnes: Prospect Books.

Gussy MG, Waters EG, Walsh O, Kilpatrick NM. 2006. Early childhood caries: current evidence for aetiology and prevention. J Paediatr Child Health 42: 37-43.

Halcrow SE, Harris NJ, Tayles N, Ikehara-Quebral R, Pietrusewsky M. 2013. From the mouths of babes: dental caries in infants and children and the intensification of agriculture in mainland Southeast Asia. Am J Phys Anthropol 150: 409420.

Hallet KB, O'Rourke PK. 2003. Social and behavioural determinants of early childhood caries. Aust Dent J 48(1): 27-33.

Harlow M, Laurence R. 2002. Growing up and growing old in Ancient Rome - a life course approach. London: Routledge.

Harlow M, Laurence R. 2007. Age and ageing in the Roman Empire. In: Harlow M, Laurence R, eds. Age and ageing in the Roman Empire. Portsmouth: J Roman Archaeol Supplementary Publications 65. p 9-24.

Heighway CM. 1980. Roman Cemeteries in Gloucester District. Trans BGAS 98: 57-72.

Hemelrijk EA. 1999. Matrona Docta - educated women in the Roman elite from Cornelia to Julia Domna. London: Routledge.

Hillson S. 1996. Dental Anthropology. Cambridge: Cambridge University Press.

Hingley R. 1989. Rural Settlement in Roman Britain. London: Seaby.

Hong L, Levy SM, Warren JJ, Broffitt B. 2009. Association between enamel hypoplasia and dental caries in primary second molars: a cohort study. Caries Res 43: 345-353.

Humphrey LT. 2010. Weaning behaviour in human evolution. Sem Cell Dev Biol 21(4): 453-461.

Hunter ML, West NX, Hughes JA, Newcombe RG, Addy M. 2000. Erosion of deciduous and permanent dental hard tissue in the oral environment. J Dent 28(4): 257-263.

Hurst HR. 1985. Kingsholm - Excavations at King- sholm Close and Other Sites with a Discussion of the Archaeology of the Area. Stroud: Gloucester Archaeological Publications.

Hurst HR. 1986. Gloucester - the Roman and later defences. Stroud: Gloucester Archaeological Publications.

Jackson R. 1988. Doctors and diseases in the Roman Empire. London: British Museum Publications.

Jones ME. 1996. The end of Roman Britain. London: Cornell University Press.

Katzenberg MA, Herring DA, Saunders SR. 1996. Weaning and infant mortality: evaluating the skeletal evidence. Yearb Phys Anthropol 39: 177 199.

Katzenberg MA. 2012. The ecological approach: understanding past diet and the relationship between diet and disease. In: Grauer AL, ed. A companion to paleopathology. Chichester: Wiley -Blackwell. p 97-113.

Kawashita Y, Kitamura M, Saito T. 2011. Early childhood caries. Int J Dent 2011: 1-7.

Killgrove K and Tykot R H, 2013. Food for Rome: a stabe isotope investigation of diet in the Imperial period (1st-3rd centuries AD). J Anthropol Archaeol 32 (1), 28-38

King AC. 1984. Animal bones and the dietary identity of military and civilian groups in Roman Britain, Germany and Gaul. In: Blagg T, King A, eds. Military and civilian in Roman Britain: cultural relationships in a frontier province. Oxford: BAR British Series 136. p 187-217.

King A. 1999. Diet in the Roman world: a regional inter-site comparison of the mammal bones. J Roman Archaeol 12: 168-202.

King A. 2001. The Romanization of diet in the Western Empire: comparative archaeological studies. In: Keay S, Terrenato N, eds. Italy and the West comparative issues in Romanization. Oxford: Oxbow Books. p 210-226.

Laes C. 2007. Inscriptions from Rome and the history of childhood. In: Harlow M, Laurence R, eds. Age and ageing in the Roman Empire. Portsmouth: J Roman Archaeol Supplementary Publications 65. p 25-36.

Laes C. 2011. Children in the Roman Empire - outsiders within. Cambridge: Cambridge University Press.

Lampl M, Johnston FE. 1996. Problems in the ageing of skeletal juveniles: perspectives from maturation assessments of living children. Am J Phys Anthropol 101: 345-355.

Larsen CS. 1997. Bioarchaeology - Interpreting Behavior from the Human Skeleton. Cambridge: Cambridge University Press. 
Laurence R, Cleary SE, Sears G. 2011. The city in the Roman west c. 250 BC - c.AD 250. Cambridge: Cambridge University Press.

Leech R. 1982. Excavations at Catsgore 1970-1973 - a Romano-British village. Taunton: Western Archaeological Trust Excavation Monograph 2.

Leech R, Besly EM, Everton RF. 1981. The excavation of a Romano-British farmstead and cemetery on Bradley Hill, Somerton, Somerset. Britannia 12: 177 $-252$.

Lewis ME. 2002. Impact of Industrialization: comparative study of child health in four sites from Medieval and Postmedieval England (A.D. 850-1859). Am J Phys Anthropol 119: 211-223.

Lewis ME. 2010. Life and death in a civitas capital: metabolic disease and trauma in the children from late Roman Dorchester, Dorset. Am J Phys Anthropol 142: 405-416.

Locker A. 2007. In piscibus diversis, the bone evidence for fish consumption in Roman Britian. Britannia 38: 141-180.

Lukacs JR. 1995. The 'Caries Correction Factor': a new method of calibrating dental caries rates to compensate for antemortem loss of teeth. Int J Osteoarchaeol 5: 151-156.

Marter A, Agruss JC. 2007. Pacifiers: an update on use and misuse. J Spec Pediatr Nurs 12(4): 278-285.

Matthews CL. 1981. A Romano-British inhumation cemetery at Dunstable. Beds Arch J 15.

Mattingly DJ. 1997. Beyond belief? Drawing a line beneath the consumer city. In: Parkins HM, ed. Roman urbanism - beyond the consumer city. London: Routledge. p 210-218.

Mattingly D. 2006. An Imperial possession - Britain in the Roman Empire. London: Penguin Group.

McCarthy M. 2013. The Romano-British peasant towards a study of people, landscapes and work during the Roman occupation of Britain. Oxford: Oxbow Books.

MacMullen R, 1987. Late Roman slavery. Historia 36 (3): 359-382.

McConnell D, Grassam A, Mustchin A. 2012. Land adjacent to Great Casterton Primary School, Pickworth Road, Great Casterton, Rutland. Bury St. Edmunds: Archaeological Solutions Limited Unpublished Report.

McDade TW, Worthman CM. 1998. The weanling's dilemma reconsidered: a biocultural analysis of breastfeeding ecology. J Dev Behav Pediatr 19(4): 286-299.

McWilliam J. 2013. The socialization of Roman Children. In: Evans Grubbs J, Parkin T, eds. The Oxford handbook of childhood and education in the Classical world. Oxford: Oxford University Press. p 264-285.
Mensforth RP, Lovejoy CO, Lallo JW, Armelagos GJ. 1978. The role of constitutional factors, diet and infectious disease in the aetiology of porotic hyperostosis and periosteal reactions in prehistoric infants and children. Med Anthropol 2: 1-59.

Millett M. 1990. The Romanization of Britain - an essay in archaeological interpretation. Cambridge: Cambridge University Press.

Millett M. 1995. Strategies for Roman small towns. In: Brown AE, ed. Roman small towns in eastern England and beyond. Oxford: Oxbow Monograph 52. p 29-38.

Millett M. 1999. Coloniae and Romano-British studies. In: Hurst H, ed. The Coloniae of Roman Britain: new Studies and a review. Portsmouth: J Roman Archaeol Supplementary Series 36. p 191-196. Millet M. 2001. Approaches to urban societies. In: James S, Millett M, eds. Britons and Romans: advancing an archaeological agenda. York: CBA Research Report 125. p 60-66.

Monfort CC. 1998. Britannia and the imports of Baetican and Lusitanian amphorae. J Iber Archaeol, 159 -172 .

Moore WJ, Corbett E. 1973. The distribution of dental caries in ancient British populations - II. Iron Age, Romano-British and Mediaeval Periods. Caries Res 7: 139-153.

Moorrees CFA, Fanning EA, Hunt EE. 1963a. Age variation of formation stages for ten permanent teeth. J Dent Res 42: 1490-1502.

Moorrees CFA, Fanning EA, Hunt EE. 1963b. Formation and resorption of three deciduous teeth in children. Am J Phys Anthropol 21: 205-213.

Morley N. 1997. Cities in context: urban systems in Roman Italy. In: Parkins HM, ed. Roman urbanism: beyond the consumer city. London: Routledge. p 42-58.

Mouritsen H. 2011. The families of Roman slaves and freedmen. In Rawson B, ed. A companion to families in the Greek and Roman worlds. Chichester: Wiley-Blackwell. p 129-144.

Moynihan P. 2000. Foods and factors that protect against dental caries. Nutr Bull 25: 281-286.

Mullin D. 2006. The archaeological landscape of Frampton-on-Severn, Gloucestershire: updated project design. Stroud: Gloucester Archaeology Service.

Müldner G. 2013. Stable isotopes and diet: their contribution to Romano-British research. Antiquity 87: 137-149.

Nassar HM, Li M, Gregory RL. 2012. Effect of honey on Streptococcus mutans growth and biofilm formation. Appl Environ Microbiol 78(2): 536-540.

Nehlich O, Fuller BT, Jay M, Mora A, Nicholson RA, Smith CI, Richards MP. 2011. Application of sul- 
phur isotope ratios to examine weaning patterns and freshwater fish consumption in Roman Oxfordshire, UK. Geochimi Cosmochim Acta 75: 4963-4977.

Nield L, Stenger J, Kamat D. 2008. Common pediatric dental dilemmas. Clin Pediatr 47(2): 99-105.

Ortner DJ. 2003. Identification of Pathological Conditions in Human Skeletal Remains (2nd edition). San Diego: Academic Press.

O'Sullivan EA, Williams SA, Wakefield RC, Cape JE and Curzon MEJ. 1993. Prevalence and site characteristics of dental caries in primary molar teeth from prehistoric times to the 18th century in England. Caries Res 27: 147-153.

Ottaway P. 2009. Roman York. Stroud: The History Press.

Ottaway PJ, Qualmann KE, Rees H, Scobie GD. 2012. The Roman cemeteries and suburbs of Winchester - excavations 1971-86. Winchester: Winchester Museums and English Heritage.

Parkins HM. 1997. The "consumer city" domesticated? The Roman city in elite economic strategies. In: Parkins HM, ed. Roman urbanism beyond the consumer city. London: Routledge. p 83-111.

Pearce J. 2008. Burial evidence from Roman Britain - the un-numbered dead. Pour une archaéologie du rite. Nouvelles perspectives de l'archaéologie funéraire, études réunies par John Scheid. Paris: Collection de L'Ecole Francaise de Rome. p 2942.

Pitts M, Griffin R. 2012. Exploring health and social well-being in Late Roman Britain: an intercemetery approach. Am J Archaeol 116(2): 253-276.

Pitts M, Perring D. 2006. The making of Britain's first urban landscapes: the case of late Iron Age and Roman Essex. Britannia 37: 189-212.

Powell ML. 1985. The analysis of dental wear and caries for dietary reconstruction. In: Gilbert RI, Mielke JH, eds. The analysis of prehistoric diets. Orlando: Academic Press. p 307-388.

Powell LA, Redfern RC, Millard AR, Gröcke DR. 2014. Infant feeding practices in Roman London: evidence from isotopic analyses. In: Carroll M, Graham E, eds. Infant health and death in Roman Italy and beyond. Portsmouth: J Roman Archaeol Supplementary Series 96. p 89-110.

Prowse TL. 2011. Diet and dental health through the life course in Roman Italy. In: Agarwal SC, Glencross BA, eds. Social bioarchaeology. Oxford: Blackwell Studies in Global Archaeology 15. p 410-437.

Prowse TL, Saunders SR, Schwarcz HP, Garnsey P, Macchiarelli R, Bondioli L. 2008. Isotopic and dental evidence for infant and young child feeding practices in an Imperial Roman skeletal sample. Am J Phys Anthropol 137: 294-308.

Rahtz P, Hirst S, Wright SM. 2000. Cannington Cemetery - Excavations 1962-3 of Prehistoric, Roman, post-Roman, and later features at Cannington Park Quarry, near Bridgwater, Somerset. London: Society for the Promotion of Roman Studies, Britannia Monograph Series 17.

Rawson B. 1966. Family life among the lower classes at Rome in the first two centuries of the Empire. Class Philol 61(2): 71-83.

Rawson B. 1986a. Children in the Roman familia. In: Rawson B, ed. The family in ancient Rome new perspectives. London: Routledge. $\mathrm{p} 170$ 200.

Rawson B. 1986b. The Roman family. In: Rawson B, ed. The family in ancient Rome - new perspectives. London: Routledge. p 1-57.

Rawson B. 1991a. Adult-child relationships in Roman society. In: Rawson B, ed. Marriage, divorce and children in ancient Rome. Oxford: Oxford University Press. p 7-30.

Rawson B. 1991b. Marriage, divorce and children in ancient Rome. Oxford: Clarendon Press.

Rawson B. 2003a. Children and childhood in Roman Italy. Oxford: Oxford University Press.

Rawson B. 2003b. The roman family in recent research: state of the question. Bib Int 11(2): 119138.

Rawson B. 2005. Circulation of staff between Roman households. Z Papyrologie Epigraphik 151: 223-224.

Redfern RC, Hamlin C, Beavan-Athfield N. 2010. Temporal changes in diet: a stable isotope analysis of late Iron Age and Roman Dorset, Britain. J Archaeol Sci 37: 1149-1160.

Redfern RC, Millard AR, Hamlin C. 2012. A regional investigation of subadult dietary patterns and health in late Iron Age and Roman Dorset. J Archaeol Sci 39: 1249-1259.

Redfern RC, DeWitte SN, Pearce J, Hamlin C, Dinwiddy KE. 2015. Urban-rural differences in Roman Dorset, England: a bioarchaeological perspective on Roman settlements. Am J Phys Anthropol 157: 107-120.

Roberts C, Cox M. 2003. Health and disease in Britain - from prehistory to the present day. Stroud: Sutton Publishing.

Rogers A. 2011. Late Roman towns in Britain - rethinking change and decline. Cambridge: Cambridge University Press.

Rogers B, Arvedson J. 2005. Assessment of infant oral sensorimotor and swallowing function. Ment Retard Dev D R 11(1): 74-82. 
Rosenthal R. 1936. A short pictorial review of the evolution of infant-feeding vessels up to the beginning of the 19th century. Bull Med Libr Assoc 25(1-2): 89-94.

Rutgers L V, van Strydonck M, Boudin M and van der Linde C, 2009. Stable isotope data from the early Christian catacombs of ancient Rome: new insights into the dietary habits of Rome's early Christians. J Archaeol Sci 36, 1127-1134

Saller R. 1991. Corporal punishment, authority and obedience in the Roman household. In: Rawson B, ed. Marriage, divorce and children in ancient Rome. Oxford: Oxford University Press. p 144-165.

Scheuer L, Black S. 2000. Developmental juvenile osteology. San Diego: Academic Press.

Scheuer L, Black S. 2004. The juvenile skeleton. London: Elsevier Academic Press.

Schuurs A. 2013. Pathology of the hard dental tissues. Chichester: Wiley-Blackwell.

Schwartz JH. 2007. Skeleton keys - an introduction to human skeletal morphology, development and analysis (2nd edition). Oxford: Oxford University Press.

Sealey PR, Davies GMR. 1984. Falernian wine at Roman Colchester. Britannia 15: 250-254.

Sealey PR, Tyers PA. 1989. Olives from Roman Spain: a unique amphora find in British waters. Antiq Journ 69(1): 53-72.

Sellen D W. 2001. Comparison of infant feeding patterns reported for nonindustrial populations with current recommendations. J Nutr 131: 2707-2715.

Sellen DW. 2007. Evolution of infant and young child feeding: implications for contemporary public health. Annu Rev Nutr 27: 123-148.

Sheridan MD. 1991. From birth to five years. Routledge: Routledge.

Shukrum S, Molto J. 2009. Childhood oral health: dental pathology of Kellis II, Dakhleh, Egypt. In: Lewis M, Clegg M, eds. Proceedings of the 9th Conference of the British Association for Biological Anthropology and Osteoarchaeology. Oxford: Archaeopress. p 19-30.

Sigismund-Nielsen H. 2007. Children for profit and pleasure. In: Harlow M, Laurence R, eds. Age and ageing in the Roman Empire. Portsmouth: J Roman Archael Supplementary Series 65. p 37-54.

Smith BH. 1991. Standards of human tooth formation and dental age assessment. In: Kelley MA, Larsen CS, eds. Advances in dental anthropology. New York: Wiley Liss. p 143-168.

Sreebny LM. 1983. Sugar and human dental caries. World Rev Nutr Diet 40: 19-65.
Stead IM, Rigby V. 1986. Baldock: the excavation of a Roman and pre-Roman settlement, 1968-72. London: Society for the Promotion of Roman Studies.

Taylor J. 2001. Rural society in Roman Britain. In: James S, Millett M, eds. Britons and Romans: advancing an archaeological agenda. York: CBA Research Report 125. p 46-59.

Temkin O. 1991. Soranus' Gynecology. Baltimore: Johns Hopkins University Press.

Todd M. 1975. Margidunum and Ancaster. In: Rodwell W, Rowley T, eds. The 'Small Towns' of Roman Britain. Oxford: BAR British Series 15. p 211-224.

Touger-Decker R, van Loveren C. 2003. Sugars and dental caries. Am J Clin Nutr 78(4): 881-892.

Ubelaker DH. 1989. Human Skeletal Remains: Excavation, Analysis, Interpretation (2nd edition). Washington: Taraxacum.

Van der Veen M. 2008. Food as embodied material culture: diversity and change in plant food consumption in Roman Britain. J Roman Archaeol 21: 83-109.

Van der Veen M, Livarda A, Hill A. 2007. The archaeobotany of Roman Britain: current state and identification of research priorities. Britannia 38: 181-210.

Van der Veen M, Livarda A, Hill A. 2008. New plant foods in Roman Britain: dispersal and social access. Environ Archaeol 13: 11-36.

Veerkamp JSJ, Weerheijm KL. 1995. Nursing-bottle caries: the importance of a developmental perspective. J Dent Child 62(6): 381-386.

Viner L, Leech R. 1982. Bath Gate cemetery, 19691976. In: McWhirr, Viner L, Wells C. Cirencester excavations II - Romano-British cemeteries at Cirencester. Cirencester: Cirencester Excavation Committee. p 69-133.

Vodanović M, Brkić H, Šlaus M, Željko D, 2005. The frequency and distribution of caries in the mediaeval population of Bijelo Brdo in Croatia (10th-11th century). Arch Oral Biol 50: 669-680

Wacher J. 1974. The Towns of Roman Britain. London: Batsford.

Wenham LP. 1968. The Romano-British cemetery at Trentholme Drive, York. London: Ministry of Public Building and Works Archaeological Reports Number 5 .

White R. 2014. The Wroxeter Hinterland Project: exploring the relationship between country and town. In: Breeze DJ, ed. The impact of Rome on the British countryside. A conference organised by the Royal Archaeological Institute, Chester, 11-13 October 2013, London: Royal Archaeological Institute Supplementary 